\title{
Performance Measure and Job Constraints: Implication for Women in Academics in Nigeria Universities
}

\author{
${ }^{1}$ Abiodun.A.Popoola, ${ }^{1}$ G.Olu Oyinloye, ${ }^{2}$ Omoniyi I. Oginni \\ ${ }^{1}$ University of Ado Ekiti, Ekiti State, Nigeria, ${ }^{2}$ University of Science \&Technology, Nigeria
}

\begin{abstract}
This study investigated the performance measure and job constraints of women academics in the Nigeria universities. The purpose was to examine the constraints of women academics in their job performance in the universities. Purposive sampling technique was adopted to select three hundred academic women from South-West Universities. Data collected were analyzed and reliability coefficient by 0.87 was obtained. The questionnaire was administered on the respondents in the various institutions. Percentages were used to analyse demographic data and answer research questions, while, t-test and multiple regression were used for hypotheses at alpha level of 0.05. It was found that performance measure and job constraints among women in academic had enabled the women to look beyond their limitations and faced their world in academics with courage and passion in order to discharge their duties favorably with their men counterparts. Recommendations includes that researches done by women be less evaluated. Women achievement should be celebrated to encourage them for the major work done at home.
\end{abstract}

\section{Introduction}

Women's roles in nations building cannot be underrated .Women all over the world are planning seriously to excel in all sphere of life. In recent years, women have put aside gender inequality, marginalization, inferiority complex, full house wife- ship. Yet, the constraint on women job is still very much with us and it is a strong enigma against the optimal performance of these set of gender in their respective organization particularly in academics. O' Connor \{7] and Ogbogu[8] found that gender and choice of job goes together. In every corner of Nigeria economy, the employers who have a long history of discrimination were required to provide formula for increasing number of women in their workforces. Davidson and Cooper [2] and Dines [3] addressed the employers and charged them not to sack pregnant women in the developed world such as United States. Women movement (2010) affirmed that women studies program was created in colleges and universities for academicians. Doors were opened for women in politics, sensitive administrative post, and head of industries, education sector and other aspects of life. Egunjobi [4] see Universities as characterized by a masculine ethic of rationality which presumably is epitomized by traits such as analytical abilities to plan their capacity to set aside personal emotional considerations in the interest of task accomplishment and cognitive superiority in problem solving and decision-making. Women therefore, need to develop masculine heart in their approach to academic work in their respective universities.

Academics, performance measures could be quantitative or qualitative. Quantitatively when examining the numbers of time that the women were present in attending lectures, meetings, seminar numbers of paper workshops, conferences, attending to students' projects etc Quantitative in terms of students' feedback, successes recorded per time, accessibility, dedication at work, best practices, reward for excellence. Job constraints on the part of women academic could be based on a number of reasons such as home factors, life expectancy, which include pregnancy, child rearing to changes in body chemistry. Others include breast feeding, attending to family problems, perception and lack of mentor and many analytical abilities to plan their capacity, to set aside personal, emotional consideration in the interest of task accomplishment and cognitive superiority in problem solving and decision making.

Performance measure ascertains how best an individual can do what helshe claims to do. It is necessary that both sex overlook their challenges in the academic world and face the reality of molding designing laws and policies that promotes their interest. Collecting and analyzing data relating to women and work, so as to bring about gender equality. Women are working seriously on how to attain key positions in the universities and other establishments. Women academic need to develop masculine heart in order to live up to expectation.

The striking inequity when it comes to gender representation in the Mathematics, Science and 
Technology fields is instrumental to performance measure analysis of women academia. A National Science Foundation (2003) found that women accounted for only 23 percent of physical scientists and 10 percent of engineers. The percentages of women on faculties in these areas are even lower, with 14 percent of science faculty members being women and a mere 6 percent in engineering departments. Moreover, the numbers are getting worse in some other areas. The percentage of women lecturers in computer and information sciences, Information and Communication Technology (ICT) such as Cisco Certified Network Administrator Oracle (CCNA) and other vital areas of global acceptability in digital networking recorded low percent involvement by the women, which peaked at 12 percent in 1984, had decreased to just 10 percent in 2004. That is a movement in the opposite direction. This country needs progress in mathematics, science, and technology. Women voice will be heard loud and clear only if they can strive and take the lead in science, technology and ICT.

In an attempt for women to blow their trumpet, special day had been promulgated by the women movement throughout the world, to address salient issues affecting them right from birth to death. These includes right to educating women trafficking, harassment inferiority complex, poverty as a result of their over-dependent on men and others Women movement serves as a vehicle for describing projects and issues related to women and a source of information for issues faced by underrepresented groups

\section{Research Rational}

Although increasing number of women has entered academia, yet they are few in higher ranks. Davidson and Cooper [2] and Dines [3] considered that women Deans and Professors are a minority group and women Vice Chancellors and Presidents are rare. A follow-up survey in 2000 by the Associations of Commonwealth Universities is not encouraging women remain disproportionately represented within instructors, lecturer and unranked positions. The researchers observed that women remain significantly underrepresented at research institutions; this is in contrast to their significant representation at primary and secondary schools.

Many years back researches have shown that home variables contributed to the trend in the university services. This study had unraveled that, there are job constraints in academics that imitate against the optimal performance of women at every stage of their profession.

\section{The Purpose of the Study}

The purpose of the study is to investigate the performance measure and job constraints as determinants of women in academics proficiency in university services.

\section{Research Question}

What are the job constraints by women in academics in university services?

\section{Research Hypotheses}

1. There is no significant difference between performance measure and job constraints in attending lectures by women academia in university services.

2. There is no significant difference between performance measure and job constraints in attending meetings by women academia in university services.

3. There is no significant difference between performance measure and job constraints in attending to students' projects by women academia in university services.

4. There is no significant difference between performance measure and job constraints in researching by women academia in university services.

5. There is no significant difference between performance measure and job constraints by women academia in university services.

\section{Methodology}

The study was a descriptive design of the survey type. The population of the study was made of all the women in academics in South-West universities in Nigeria. The sample was made of three hundred women in academics between ages 20 - 60 years in the South-West of Nigeria. They were selected by purposive sampling technique from six universities in Nigeria. The instrument for the study was a 30-item questionnaire constructed by the researchers and titled Performance measure and job constraints: Implication for women academia in Nigeria universities. Possible constraints include: child rearing, child care, home making, attending to visitors, attending to family problems, attending to extended family problems, attending to husband problems and others. The instrument was validated by experts and a testretest method of reliability was used, using Pearsons' Product Correlation analysis with reliability coefficient of 0.87 which was adjudged 
adequate for the study. The instrument was administered on the respondents in the various institutions during school period. Data collected were pre-coded, and analyzed using frequency counts, percentages, t-test, Multiple Regression and F-ratio with decision taken at 0.05 level of significant.

\section{Results}

\subsection{Descriptive Analysis}

The findings are shown in Table 1.

What are job constraints by women in academics in university services?

Table 1. Job constraints that determines performance, measured by women academics in the University

\begin{tabular}{|l|l|l|l|l|l|}
\hline S/N & \multicolumn{1}{|c|}{ Items } & \multicolumn{2}{l|}{ Agree } & \multicolumn{2}{l|}{ Disagree } \\
\hline S/N & Constraints & F & $\%$ & F & $\%$ \\
\hline 1 & Attending to visitors & 213 & 71 & 87 & 29 \\
\hline 2 & Child rearing & 189 & 63 & 57 & 37 \\
\hline 3 & Child care & 172 & 57 & 128 & 43 \\
\hline 4 & Domestic work & 164 & 55 & 136 & 45 \\
\hline 5 & Early Pregnancy & 202 & 67 & 98 & 33 \\
\hline 6 & Home cleaning & 231 & 77 & 69 & 23 \\
\hline 7 & Social engagements & 118 & 39 & 182 & 61 \\
\hline
\end{tabular}

Table 1 shows that majority of the respondents 213 (71\%) agree on attending to visitors as one of the job constraints by women in academics in the universities services. while, only $87(29 \%)$ of the respondents indicated their disagreement. Only $189(63 \%)$ of the respondents agree with $57(37 \%)$ disagreement to child rearing as one of the job constraints by women in academics in the universities services. As indicated, only 172(57\%) respondents agree with $128(43 \%)$ disagreement on child care as one of the job constraints by women in academics in the university services. Only $164(55 \%)$ of the respondents agree with 136(45\%) disagreement on domestic work as one of the job constraints by women in academics in the university services. Also, respondents agree on attending early pregnancy 202(67\%), while, 98(33\%) disagree. Similarly, respondents agree $231(77 \%)$ to performance measure with 69(23\%) disagreement on home cleaning as one of job constraints by women in academics in the university services. Attending to visitors and home cleaning had the highest contribution to job constraints by women in Academics in the universities services.

\subsection{Hypotheses Testing}

Hypothesis 1

1. There is no significant difference between job constraints and attending lectures by women academia in university services.

Table 2. t-test of job constraints and attending lectures by women in academics

\begin{tabular}{|l|l|l|l|l|l|l|}
\hline Variables & $\mathrm{N}$ & Mean & SD & Df & R & t-cal \\
\hline $\begin{array}{l}\text { Performance } \\
\text { Measure }\end{array}$ & 300 & 59.60 & 4.88 & & & \\
\cline { 1 - 4 } $\begin{array}{l}\text { Attending } \\
\text { Lectures }\end{array}$ & 300 & 17.83 & 3.68 & 299 & .736 & 126.6 \\
\hline
\end{tabular}

$\mathrm{p}>0.05$

Table 2 shows that t-cal (126.60) value is greater than t-Table (1.960) value at 0.05 level of significant. Hence, the null hypothesis is rejected. This implies that there is significant difference between home factors and attending lectures by women in academics. Again, r-cal (.736) value is greater than r-Table (0.195) value at 0.05 level of significant.

\section{Hypothesis 2}

2. There is no significant difference between job constraints and attending meetings by women academia in university services.

Table 3. t-test of job constraints and attending Meetings by women in academics

\begin{tabular}{|l|l|l|l|l|l|r|}
\hline Variables & $\mathrm{N}$ & Mean & SD & Df & $\mathrm{R}$ & $\mathrm{t}$-cal \\
\cline { 1 - 6 } $\begin{array}{l}\text { Home } \\
\text { factors }\end{array}$ & 300 & 67.54 & 5.89 & 299 & .766 & 125.69 \\
\cline { 1 - 4 } $\begin{array}{l}\text { Attending } \\
\text { meetings }\end{array}$ & 300 & 24.46 & 3.54 & & & \\
\hline
\end{tabular}

$\mathrm{p}>0.05$

Table 3 shows that $t$-cal (125.69) value is greater than t-table (1.960) value at 0.05 level of significant. The null hypothesis is rejected. This implies that there is significant difference between home factors and attending meetings by women in academics. Again, r-cal (.766) value is greater than r-Table (0.195) value at 0.05 level of significant. 
Hypothesis 3

3. There is no significant difference between job constraints and attending to students' supervision by women academia in university services.

Table 4. t-test of job constraints and attending to students' supervision by women in academics

\begin{tabular}{|c|c|c|c|c|c|c|}
\hline Variables & $\mathrm{N}$ & Mean & SD & $\mathrm{Df}$ & r-cal & $\mathrm{t}-\mathrm{cal}$ \\
\hline $\begin{array}{l}\text { Home } \\
\text { factors }\end{array}$ & 300 & 5.78 & 6.31 & \multirow[t]{2}{*}{299} & \multirow[t]{2}{*}{.377} & \multirow[t]{2}{*}{121.35} \\
\hline $\begin{array}{l}\text { Students } \\
\text { supervision }\end{array}$ & 300 & 6.12 & 2.62 & & & \\
\hline
\end{tabular}

$\mathrm{p}>0.05$

Table 4 shows that $\mathrm{t}$-cal (121.35) value is greater than t-Table (1.96) value at 0.05 level of significant. The null hypothesis is rejected. This implies that there is significant difference between home factors and attending to students' projects by women in academics. Again, r-cal (.377) value is greater than r-Table (0.195) value at 0.05 level of significant.

Hypothesis 4

4. There is no significant difference between job constraints and researching by women academia in university services.

Table 5. t-test of job constraints and researching by Women in Academics

\begin{tabular}{|l|l|l|l|l|l|l|}
\hline Variables & $\mathrm{N}$ & Mean & SD & df & R & t-cal \\
\cline { 1 - 5 } $\begin{array}{l}\text { Performance } \\
\text { measure }\end{array}$ & 300 & 56.48 & 5.80 & & & \\
\cline { 1 - 5 } Researching & 300 & 32.62 & 1.53 & 299 & .630 & 120.96 \\
\hline
\end{tabular}

$\mathrm{p}>0.05$

Table 5 shows that t-cal (120.96) value is greater than t-Table (1.96) value at 0.05 level of significant. The null hypothesis is rejected. This implies that there is significant difference between home factors and researching by women in academics. Again, r-cal (.63) value is greater than r-Table (0.195) value at 0.05 level of significant.

Hypothesis 5

There is no significant impact between performance measure and job constrainst by women in academics
Table 6. Regression analysis showing the impact of home factors on job performance by women in academics in university services

\begin{tabular}{|c|c|c|c|c|c|c|c|c|}
\hline Model & B & $\begin{array}{l}\text { Std. } \\
\text { Error }\end{array}$ & Beta & $\mathrm{T}$ & $\begin{array}{l}\text { Sig } \\
\text {.T }\end{array}$ & $\mathrm{R}$ & $\mathrm{R}^{2}$ & $\mathrm{~F}$ \\
\hline Constant & 51.67 & 4.433 & & 12.37 & .00 & \multirow{8}{*}{.276} & \multirow{8}{*}{.067} & \\
\hline $\begin{array}{l}\text { Attending } \\
\text { to visitors }\end{array}$ & 1.542 & .516 & -.236 & 2.717 & .00 & & & \\
\hline $\begin{array}{l}\text { Child } \\
\text { rearing }\end{array}$ & .039 & .0223 & .138 & 1.683 & .07 & & & 3 \\
\hline Child care & .532 & .403 & .122 & 1.237 & .22 & & & 5 \\
\hline $\begin{array}{l}\text { Domestic } \\
\text { work }\end{array}$ & 2.464 & 1.173 & -.192 & 2.530 & .03 & & & 8 \\
\hline $\begin{array}{l}\text { Early } \\
\text { Pregnancy }\end{array}$ & .632 & .874 & .074 & .792 & .39 & & & \\
\hline $\begin{array}{l}\text { Home } \\
\text { Cleaning }\end{array}$ & .823 & 1.173 & .056 & .624 & .43 & & & \\
\hline $\begin{array}{l}\text { Social } \\
\text { engagement }\end{array}$ & 1.32 & 1.465 & .066 & .997 & .32 & & & \\
\hline
\end{tabular}

Dependent variable: Job performance

Model specification

$\mathrm{Y}=\mathrm{b}_{\mathrm{o}}+\mathrm{b}_{1} \mathrm{X}_{1}+\mathrm{b}_{2} \mathrm{X}_{2}+\mathrm{b}_{3} \mathrm{X}_{3}+\mathrm{b}_{4} \mathrm{X}_{4}+\mathrm{b}_{5} \mathrm{X}_{5}+\mathrm{b}_{6} \mathrm{X}_{6}+\mathrm{b}_{7} \mathrm{X}_{7}+\mathrm{U}$

0

$=51.67-1.542 \mathrm{X}_{1}+.0 .039 \mathrm{X}_{2}+.532 \mathrm{X}_{3}-$

$2.464 \mathrm{X}_{4}+.632 \mathrm{X}_{5}+.823 \mathrm{X}_{6}+1.32 \mathrm{X}_{7}+\mathrm{U}_{0}$

$\mathrm{T}=(12.37)(-2.717$ (1.683) (1.237) $(-2.530 *)(.792)$

(.624)(.997)*

Std.err $=(4.423)(.516)(.0223)(.403)(1.173)(.874)(1$. 173)(1.465)

$\mathrm{R}=.276, \mathrm{R}^{2}=.067, \mathrm{~F}=3.58$

Where

$\mathrm{X}_{1}=$ Attending to visitors

$\mathrm{X}_{2}=$ Child rearing

$\mathrm{X}_{3}=$ Child care

$\mathrm{X}_{4}=$ Domestic work

$\mathrm{X}_{5}=$ Early Pregnancy

$\mathrm{X}_{6}=$ Home Cleaning

$\mathrm{X}_{7}=$ Social engagements

$\mathrm{U}_{\mathrm{i}}=$ Stochastic Error term

$\mathrm{b}_{0}=$ constant term

Table 6 shows that, out of all the criterion variables, only attending to lectures $(\mathrm{t}=-2.717$, $\mathrm{P}<0.05)$ domestic work $(\mathrm{t}=-2.530), \quad \mathrm{P}<0.05)$ impacted significantly on job constraints and performance measure of women in academics. In contrast, the impact of Child rearing $(t=1.683$, $\mathrm{P}>0.05)$, Child care $(\mathrm{t}=1.237, \mathrm{P}>0.05)$, Early pregnancy $(\mathrm{t}=.79, \mathrm{P}>0.05)$, Attending to visitors $(t=.624, P>0.05)$ and Social engagements $(t=.995$, $\mathrm{P}>0.05$ ) is not significant at 0.05 level. The composite relationship between the independent variables (home factors) and the dependent variables (job performance) is low, positive and significant at 0.05 level $(r=.268, \mathrm{p}>0.05)$. Home factors only account for $7 \%$ of the variation in job performance. The remaining 93\% variation in job 
performance is largely due to other variables outside the regression model which are otherwise included in the stochastic error term. The regression model is significant in terms of its overall goodness of fit $(\mathrm{F}=2.678, \mathrm{p}<0.05)$.

\section{Discussion}

The study revealed that indeed home factors have significant impact on job performance by women in academics in the university services. This is better explained by the findings of Ogbogu [8] which confirmed that gender factors had effect on female labour input in Nigerian university system. Egunjobi [4] found that majority of women in academics will have to do many things if not all before coming to attend to university services. Jamal [5] buttressed this by saying that "there is job stress experienced by women in academics". Also, O'Connor [7] found gender and job difference in their studies, however, the present study agrees with Ogbogu [8], and Nom, Onyeka and Jumai [6].

\section{Conclusion and Recommendations}

There is a strong need to move closer to women in academics on how to perform their services as academia. The well being by women in academics in the universities services should not be left alone. There is need for more research on Women in academics in the universities services, since they are always marginalized despite their bulk of work both at home as well as in the system. It is believed that, if adopted and implemented, the findings from these study is capable of transforming women in academics in the universities services and also make them to be more active in their job. In order to solve the problems of the unending home variables the Federal and State Government in Nigeria can provide for a variety of paid and unpaid leaves which will enable women to attend to family responsibilities. It should be noted that, every family serves as the foundation of every society. Women are the home makers if their work is given greater priority at the expense of the family; they are running a risk of losing the home. Hence adequate support should be provided for women in academics in order to function well in the system. Under the Federal Pregnancy Discrimination Act of 1978, which is part of Title VIII of the Civil Right Act 1964, universities must provide the pregnancy leaves for women under institutional benefit programs. Routine check must be given its own place for normal pregnancy and birth. The implication for these is that it changes women from being a full house wife to academia and are both widespread and dramatic. Contrary to the beliefs that the husband economic strength determines the wife's survival and upkeep, today women are seen as home markers and roll model in the society; hence they take active parts in the home up keep and their roll is very important and should not be undermined. Most often research done by women is evaluated more critically than men, there should be less of this. Women achievement should be celebrated to encourage other women function well and perform their roles both at work and at home.

\section{References}

[1] Awe, B. The role by women in management in the 90s. Journal of Management in Nigeria. 26(6), 13-15. 1990.

[2] Davidson M.J \& Cooper C.L Shattering the glass ceiling. The Woman Manager. London Paul

Chapman.1992

[3]Dines E. Women in Higher Education Management Paris. UNESCO/ Commonwealth Secretariat. 1993.

[4]Egunjobi O.A., Women in Academics: The untold story of gender inequality and Discrimination against women in the Ivory Tower, Multidisciplinary Publication, (1) (1). 2009.

[5]Jamal, M. O., Job stress and job performance controversy:AnEmpirical, Assessment Organization Behavior and Human Performance, 32,1-21. 1984

[6] Nom A.U.T, Onyeka, I., and Jumai, J.L (2008) Gender Analysis in National Open University of Nigeria (NOUN) Journal of Applied Science Research, 4(7), 814-825.

[7] O'Connor, O. Resistance in Academia paper presented to NAWE International Conference on Women in Higher Education New Orleans 2000.

[8]Ogbogu C.O., Gender factors affecting female labour input in Nigerian university

system.Retievedwww.co.uk/Distant Learning 2010 (Access Date: 20, April 2010).

[9]Oloruntoba, A. \& Ajayi, T., Gender and Research Attainment in Nigeria Agricultural Universities JHEA/RESA 4(2), 83-98. 2006.

[10]White, K., Being Ignored. A case study by women in the professoriate in Australia. Paper presented to the $2^{\text {nd }}$ Europe Conference on Gender Equality in Higher Education Zuric. 